\title{
PERLINDUNGAN HUKUM DAN HAK ASASI MANUSIA TERHADAP PEKERJA KONTRAK (OUTSOURCING) DI KOTA AMBON
}

\author{
Oleh: Barzah Latupono
}

\begin{abstract}
outsourcing sebagai mahluk Tuhan Yang Maha Esa yang juga memiliki hak asasi. Salah satu bentuk hak asasi pekerja kontrak adalah mendapatkan jaminan untuk dilindungi sesuai dengan nilai-nilai agama dan kemanusiaan serta pancasila dan tujuan Negara yang tercantum dalam UUD 1945. Perlindungan terhadap pekerja dimaksudkan untuk menjamin hak-hak dasar pekerja dan menjamin kesamaan kesempatan serta perlakuan tanpa diskriminasi atas apapun untuk mewujudkan kesejatraan pekerja dan keluarganya dengan tetap memperhatikan perkembangan kemajuan dunia usaha dan kepentingan pengusaha. Peraturan perundangundangan yang terkait dengan perlindungan bagi pekerja yakni Undang-Undang no 13 Tahun 2003 tentang ketenaga kerjaan dan peraturan pelaksana dari perundang-undangan dibidang ketenagakerjaan.
\end{abstract}

Keyword: Outsourcing

\section{A. LATAR BELAKANG.}

Pembangunan nasional dilaksanakan dalam rangka pembangunan manusia Indonesia seutuhnya dan pembangunan masyarakat indonesia seluruhnya untuk mewujudkan masyarakat yang sejaterah, adil dan makmur yang merata baik materil maupun spiritual berdasarkan pancasila dan Undand-Undang Dasar Negara repoblik Indonesia Tahun 1945. Di dalam pembangunan nasional, pekerja mempunyai peranan dan kedudukan yang sangat penting sebagai pelaku dan tujuan pembangunan. Sesuai dengan peranan dan kedu hukum dan hak asasi manusia terhadap pekerja dan keluarganya sesuai dengan harkat dan martabat kemanusiaaan.

Perlindungan hukum dan hak asasi manusia terhadap pekerja merupakan pemenuhan hak dasar yang melekat dan dilindungi oleh konstitusi sebagaimana yang diatur dalam pasall 27 ayat (2) UndangUndang dasar negara republik Indonesia tahun1945 yang berbunyi “ Tiap-tiap warga negara berhak atas pekerjaan dan penghidupan yang layak bagi kemanusiaan", Pasal 33 ayat (1) yang menyatakan bahwa" Pereknomian disusun sebagai usaha bersama atas kekeluargaan", dengan demikian pelanggaran terhadap hak dasar yang dilindungi oleh konstitusi merupakan pelanggaran hak asasi manusia.

Perlindungan terhadap pekerja dimaksudkan untuk menjamin hak-hak dasar pekerja dan menjamin kesamaan kesempatan serta perlakuan tanpa diskriminasi atas apapun untuk mewujudkan kesejatraan pekerja dan keluarganya dengan tetap memperhatikan perkembangan kemajuan dunia usaha dan kepentingan pengusaha. Peraturan perundang-undangan yang terkait dengan perlindungan bagi pekerja yakni Undang-Undang no 13 Tahun 2003 tentang ketenaga kerjaan dan peraturan pelaksana dari perundang-undangan dibidang ketenagakerjaan. 
Permasalahan ketenagakerjaan di indonesia saat ini terkait dengan hubungan kerja tidak seimbang antara pengusaha dangan pekerja dalam pembuatan perjanjian kerja. Selain itu adanya perkembangan ekonomi global dan kemajuan teknologi yang demikian cepat membawa dampak timbulnya persaingan usaha yang begitu ketat yang menyebabkan perusahaan melakukan proses efisiensi dan efektivitas perusahaan, salah satunya dengan mengurangi jumlah sumber daya manusia dalam hal ini pekerja yang ada. Salah satu cara untuk melakukan perampingan sumber daya manusia tersebut, perusahaan umumnya menggunakan sistim kontrak (outsourcing).

Sistim kontrak (outsourcing) diartikan sebagai pemindahan atau pendelegasian beberapa proses bisnis kepada suatu badan penyedia jasa, dimana badan penyedia jasa tersebut melakukan proses administrasi dan manajemen berdasarkan defenisi serta kriteria yang telah disepakati oleh para pihak. Dalam hukum ketenagakerjaan di Indonesia (pasal 64 Undang-undang nomor 13 Tahun 2003 tentang ketenagakerjaan), sistim kontrak (outsourcing) diartikan sebagai pemborongan pekerjaan dan penyedia jasa tenaga kerja.

\section{Dalam}

perkembangannya, perusahaan yang menggunakan sistim outsourcing akan menyebabkan kedudukan dan hubungan kerja antara pekerja dan pengusaha menjadi tidak seimbang. Hal ini berdampak pada posisi tawar pekerja menjadi semakin lemah karena tidak ada kepastian kerja, kepastian upah,, jaminan sosial, jaminan kesehatan, pesangon jika di PHK, tunjangan-tunjangan dan kepastian lain. Selain itu akan memberi kesempatan yang lebih mudah bagi perusahaan yang bersangkutan untuk menambah atau mengurangi kesempatan kerja pada pekerja sehingga dapat merugikan pekerja tersebut.

Keadaan pekerja yang hak-haknya diabaikan oleh pengusaha tersebut seolaholah mendapatkan pembenaran dan jastifikasi dari pemerintah melalui undang_undang ketenagakerjaan yang mengijinkan sistim penyerahan sebagian pekerja pada pihak lain (outsourcing), ini sangat bertentangan dengan jiwa dan semangat dari Pembukaan UUD Negara repoblik Indonesia Tahun 1945 dan pasal 27 ayat (2) UUD 1945, dan UU No 13 Tahun 2003 tentang Ketenagakerjaan, dimana pembukaan UUD Negara repoblik Indonesia Tahun 1945 menyatakan bahwa: "Negara Indonesia melindungi segenap bangsa Indonesia dan seluruh tumpah darah indonesia, memajukan kesejatraan umum, mencerdaskan kehidupan bangsa dan ikut melaksanakan ketertiban dunia berdasarkan kemerdekaan perdamaian abadi dan keadilan sosial berdasarkan pancasila.

Dalam pasal 27 ayat(2) UUD Negara Repoblik Indonesia Tahun 1945 menyatakan bahwa: Setiap warga negara berhak atas pekerjaan dan penghidupan yang layak bagi kemanusiaan. Dari amanat pembukaan UUD Negara Repoblik Indonesia Tahun 1945 dapat kita pahami bahwa tujuan pembangunan ketenagakerjaan adalah menciptakan lapangan pekerjaan bagi warga negara untuk mendapatkan penghidupan yang layak.

Dalam UU No 13 Tahun 2003 tentang ketenagakerjaan telah mengatur perlindungan terhadap hak-hak pekerja antara lain:

1. Hak atas upah yang layak.

2. Hak perlindungan atas keselamatan dan kesehatan kerja, termasuk hak istirahat dan cuti.

3. Hak atas PHK.

4. Hak untuk mogok kerja dan sebagainya.

Dalam praktek penyerahan sebagian pekerja pada pihak lain (outsourcing), hakhak tersebut merupakan sesuatu yang sangatlah sulit untuk di dapat oleh para pekerja kontrak (outsourcing).

Berdasarkan uraian latarbelakang tersebut, maka permasalahan yang dapat dikemukakan adalah: 
1. Bagaimana perlindungan hukum terhadap hak-hak pekerja kontrak(outsourcing) sebagai hak asasi manusia?

2. Bagaimana implementasi perlindungan hukum dan hak asasi manusia terhadap pekerja kontrak (outsourcing) di Kota Ambon?

\section{B. PEMBAHASAN}

\section{Pengertian Pekerja Kontrak}

Menurut ketentuan Undang-undang No. 13 Tahun 2003 tentang Ketenagakerjaan di dalamnya diberikan batasan tentang pengertian ketenagakerjaaan sebagai berikut:

1. Ketenagakerjaan adalah segala sesuatu yang berhubungan dengan tenaga kerja pada waktu sebelum, dan setelah selesainya masa hubungan kerja.

2. Tenaga kerja adalah objek, yaitu setiap orang yang mampu melakukan pekerjaan untuk menghasilkan barang atau jasa untuk kebutuhan sendiri dan orang lain.

3. Pekerja atau buruh adalah setiap orang yang bekerja untuk orang lain dengan menerima upah berupa uang atau imbalan dalam bentuk lain.

4. Pemberi kerja adalah orang-orang perseorangan atau badan hukum yang mempekerjakan orang lain dengan membayar upah atau imbalan dalam bentuk lain.

Karyawan kontrak dalam perarturan ketenagakerjaan di Indonesia memang diperbolehkan dan sudah diatur. Kontrak kerja untuk karyawan sejatinya dimaksudkan untuk diberlakukan kepada pekerjaan-pekerjaan yang memiliki karekteristik tertentu, yaitu :

1. Pekerjaan yang selesai atau sementara sifatnya.

2. Pekerjaan yang diperkirakan penyelesaiannya dalam waktu yang tidak terlalu lama dan paling lama 3 (tiga) tahun.

3. Pekerjaan yang bersifat musiman.
4. Pekerjaan yang berkaitan dengan produk baru, kegiatan baru atau produk tambahan yang masih dalam percobaan atau penjajakan.

Karyawan kontrak adalah karyawan yang diperbantukan untuk menyelesaikan pekerjaan-pekerjaan rutin perusahaan, dan tidak ada jaminan kelangsungan masa kerjanya. Dalam hal ini kelangsungan masa kerja karyawan kontrak ditentukan oleh prestasi kerjanya. Apabila prestasi kerjanya baik, akan diperpanjang kontrak kerjanya. Dampak psikis dari ketentuan yang menyatakan masa kerja karyawan kontrak tergantung pada prestasi kerjanya adalah karyawan kontrak menjadi mempunyai motivasi berprestasi yang tinggi. Hal ini dikarenakan karyawan menginginkan untuk dapat terus bekerja dan mendapatkan penghasilan dari pekerjaannya. Penghasilan tersebut dipergunakan karyawan untuk mencukupi kebutuhan hidupnya dan keluarganya.

Seseorang yang dikontrak biasanya beban kerjanya hampir sama atau bahkan lebih berat dari pada pegawai tetap, namun dari segi gaji atau fasilitas lainnya tentu saja sangat berbeda. Bayangkan saja berapa keuntungan perusahaan dari segi produktifitas misalnya, termasuk tidak adanya ketentuan pesangon yang jelas apabila perusahaan tidak lagi menggunakan jasa si tenaga kerja kontrak. Banyak perusahaan outsourcing (penyedia tenaga kontrak) yang melihat peluang ini. Sehingga perusahaan yang membutuhkan pegawai kontrak tinggal memesan sesuai kualifikasi yang diinginkan. Namun persoalan yang ditimbulkan akibat sistem kontrak ini seakan tak berkesudahan. Mulai dari PHK sepihak, tidak adanya pesangon yang memadai, dan terlebih lagi tidak adanya perlindungan hukum bagi karyawan kontrak yang akan menuntut haknya di pengadilan.

Bila merujuk kepada aturan yang berlaku, jenis hubungan kerja PKWT hanya dapat diterapkan untuk 4 jenis pekerjaan, yaitu pekerjaan yang sekali selesai, pekerjaan yang bersifat musiman, pekerjaan 
dari suatu usaha baru, produk baru atau kegiatan baru, serta pekerjaan yang sifatnya tidak teratur (pekerja lepas).

Ketentuan yang berlaku untuk karyawan kontrak adalah sebagai berikut:

1. Karyawan kontrak dipekerjakan oleh perusahaan untuk jangka waktu tertentu saja, waktunya terbatas maksimal hanya 3 tahun.

2. Hubungan kerja antara perusahaan dan karyawan kontrak dituangkan dalam "Perjanjian Kerja Untuk Waktu Tertentu".

3. Perusahaan tidak dapat mensyaratkan adanya masa percobaan.

4. Status karyawan kontrak hanya dapat diterapkan untuk pekerjaan tertentu yang menurut jenis dan sifat atau kegiatan pekerjaannya akan selesai dalam waktu tertentu, yaitu :

a. Pekerjaan yang sekali selesai atau yang sementara sifatnya

b. Pekerjaan yang diperkirakan penyelesaiannya dalam waktu yang tidak terlalu lama dan paling lama 3 (tiga) tahun ;

c. Pekerjaan yang bersifat musiman; atau

d. Pekerjaan yang berhubungan dengan produk baru, kegiatan baru, atau produk tambahan yang masih dalam percobaan atau penjajakan.

e. Untuk pekerjaan yang bersifat tetap, tidak dapat diberlakukan status karyawan kontrak.

5. Apabila salah satu pihak mengakhiri hubungan kerja sebelum berakhirnya jangka waktu yang ditetapkan dalam perjanjian kerja waktu tertentu, atau berakhirnya hubungan kerja bukan karena terjadinya pelanggaran terhadap ketentuan yang telah disepakati bersama, maka pihak yang mengakhiri hubungan kerja diwajibkan membayar ganti rugi kepada pihak lainnya sebesar gaji karyawan sampai batas waktu berakhirnya jangka waktu perjanjian kerja.

6. Jika setelah kontrak kemudian perusahaan menetapkan ybs menjadi karyawan tetap, maka masa kontrak tidak dihitung sebagai masa kerja.

Perbedaan pokok antara karyawan tetap dan kontrak terletak pada batas masa berlakunya hubungan kerja dan hak pesangon apabila hubungan kerja terputus. Artinya karyawan yang selesai kontrak tidak berhak atas pesangon, sedangkan karyawan tetap yang di-PHK yang memenuhi syarat dan ketentuan tertentu berhak atas pesangon.

\section{Harkat dan Martabat Pekerja Kontrak \\ Berbicara tentang harkat dan} martabat pekerja kontrak maka tidak dapat dilepaskan sebagai harkat dan martabat manusia, dimana pekerja kontrak sebagai seorang manusia mempunyai harkat dan martabat yang sama dengan manusia lainnya. Hak-hak pekerja kontrak merupakan hak asasi manusia telah disepakati untuk dijunjung tinggi dan dihormati harkat dan martabatnya baik dalam bidang privat maupun publik, pekerja kontrak menjadi bagian dari pelaku sejarah peradaban manusia atau warga bangsa yang tidak dapat diingkari oleh siapapun.

Hampir semua masyarakat di dunia masih ditandai sikap yang menganggap bahwa pekerja kontrak lebih rendah kedudukan dan nilainya dibandingkan dengan pekerja tetap. Sumbangan pekerja kontrak bagi kehidupan keluarga dan masyarakat, maupun sumbangan di dunia kerja atau bagi pertumbuhan ekonomi masih sangat kurang diakui dan dihargai. Hal ini menyebabkan pekerja kontrak pada umumnya kurang atau sama sekali tidak berperan dalam proses pengambilan keputusan dalam suatu lapangan pekerjaan atau badan usaha yang digeluti.

Hal ini menjadi menarik karena sudah sejak dari dahulu kita ingin mengangkat harkat dan martabat tenaga kerja Indonesia. Pada masa lalu kita sering melakukan promosi investasi ke luar negeri dengan dua keunggulan komparatif, pertama bahwa peluang pasar di dalam negeri sangat 
besar dan yang kedua biaya tenaga kerja Indonesia adalah murah. Keunggulan komparatif kedua ini seharusnya di ubah dan tidak digunakan lagi. Sungguh kurang manusiawi kalau kita tetap mempertahankan satu citra bahwa tenaga kerja kita murah. Oleh sebab itu, kita telah memiliki undangundang tersendiri mengenai ketenagakerjaan. Undang-undang ini mengatur segala sesuatu yang bersangkutan dengan hak dan kewajiban para pekerja, termasuk hak dan kewajiban perusahaan tempat mereka bekerja. Tampaknya berbagai pengaturan yang diterapkan di dalam dunia kerja ini masih dirasa berat bagi para calon investor dari luar. Salah satu cara yang dikembangkan untuk mengatasi permasalahan ini adalah dengan mengembangkan sistem tenaga kerja kontrak.

Berbicara tentang harkat dan martabat pekerja kontrak maka berdasarkan hasil penelitian tergambar bahwa para pekerja kontrak yang berada di Kota Ambon tidak mempunyai harkat dan martabat, padahal dalam HAM setiap orang itu mempunyai harkat dan martabat yang harus dijunjung tinggi oleh dirinya pribadi maupun oleh orang lain. Karena dengan membiarkan seorang pekerja kontrak yang bekerja untuk kemajuan tempat usahanya dengan tidak diperhatika hak-haknya merupakan pelanggaran terhadap harkat dan martabat pekerja kontrak selaku manusia, selain itu perbuatan ini juga bertentangan dengan falsafah kehidupan bangsa Indonesia serta melanggar aturan hukum kitab undangundang hukum pidana dan perbuatan semacam ini terjadi di Kota Ambon, dimana pekerja kontrak dieksploitasi sebagai Pekerja tanpa mempedulikan hak-haknya tapi karena untuk memenuhi kebutuhan ekonominya, maka mereka tidak bisa berbuat banyak. Untuk itu pemerintah selaku pihak yang bertanggung jawab terhadap pemenuhan hak asasi manusia harus berani mengambil langkah demi untuk menegakkan harkat dan martabat pekerja kontrak di Kota Ambon, karena apabila dengan alasan untuk menafkahi keluarganya secara tergesa-gesa kondisi ini mengakibatkan seorang pekerja kontrak bekerja tanpa menandatangani kontrak kerja atau pekerja yang sudah menandatangani kontrak kerja tapi tidak bisa melamar menjadi PNS di tempat lain sebelum habisnya masa kontrak.

Sedangkan di tempat bekerjanya tidak diangkat menjadi pegawai tetap, lalu tiba-tiba dia dinon aktifkan, dia tidak pernah diberikan uang pesangon atau ganti rugi lainnya padahal sudah puluhan tahun dia bekerja diperusahaan tersebut. Ini berarti bahwa pemerintah telah melakukan tindakan kekerasan terhadap pekerja kontrak dengan membiarkan para pengusaha atau pemilik usaha melakukan tindakan sewenangwenang kepada pekerjanya tanpa bisa melakukan apa-apa. Untuk itu pemerintah harus membuat kebijakan-kebijakan yang berpihak kepada pekerja kontrak agar tidak lagi direndahkan harkat dan martabatnya sebagai manusia.

Pemahaman hukum bagi pekerja kontrak dan pihak yang terlibat di dalamnya yang juga termasuk pemerintah sangat penting agar supaya akan tercapai kepastian, penegakkan dan perlindungan hukum seperti yang diinginkan kepada para pekerja kontrak. Pemahaman hukum ini terkait dengan tingkat pendidikan yang dimiliki seperti yang dijelaskan didepan bahwa pemahaman hukum dari para pihak tentang perlindungan hukum terhadap pekerja kontrak itu sangat kurang hal ini terkait dengan tingkat pendidikan dan kurangnya sosialisasi yang diberikan oleh pemerintah tentang peraturan tersebut.

Penegakkan hukum merupakan upaya untuk melakukan perlindungan hukum yang dimaksudkan di sini adalah perlindungan hukum (law protection) yang memberikan rasa aman dan pasti, atau rasa terlindungi oleh peraturan prundangundangan (perlindungan terhadap hak asasi manusia) dari perbuatan-perbuatan yang tidak bertanggung jawab dan bersifat merendahkan harkat dan martabat pekerja kontrak. 
Sehingga perlu diadakan sosialisasi hukum secara intensif dan berkelanjutan agar masyarakat dapat memahami tentang undang-undang perlindungan hukum terhadap pekerja kontrak, supaya para pihak dalam Pelaksanaan pekerja kontrak dapat mengetahui tentang arti pentingnya hukum yang melindungi mereka selaku pekerja.

Menurut Soerjono Soekamto dan Muatafa Abdullah (1987: 229) pemahaman hukum adalah seorang warga masyarakat mempunyai pengetahuan dan pemahaman mengenai aturan-aturan tertentu, terutama dari segi isinya. Pendapat ini dipertegas lagi oleh Otje salman (1969:57), bahwa pemahaman hukum adalah sejumlah informasi yang dimiliki seseorang mengenai isi peraturan dari suatu hukum tertentu. Dengan lain perkataan, pemahaman hukum adalah suatu pengertian terhadap isi dan tujuan dari suatu peraturan hukum tertentu, tertulis maupun tidak tertulis, serta mempunyai manfaat bagi pihak-pihak yang kehidupannya diatur oleh peraturan tersebut.

Peraturan perundang-undangan yang dimaksudkan disini adalah perangkat aturan yang mengatur perlindungan tentang hak asasi manusia pekerja yang dituangkan dalam undang-undang No 39 Tahun 1999 dan Undang-Undang Nomor 13 Tahun 2003 tentang tenagakerjaan yang di dalamnya termuat pasal-pasal tentang hak asasi seorang pekerja.

Pemahaman tentang peraturan perundang-undangan yang mengatur tentang pekerja kontrak ini yang diutamakan adalah pemahaman yang baik dan benar dari aparat pemerintah, karena mereka merupakan salah satu penentu berfungsinya hukum atau undang-undang tersebut.

$$
\text { Dalam hubungannya dengan }
$$
berfungsinya hukum maka, Soerjono Soekamto (1986:55) menjelaskan bahwa: "Petugas penegak hukum mencakup ruang lingkup yang sangat luas pada strata atas, menengah, dan bawah. Yang jelas adalah, bahwa di dalam melaksanakan tugastugasnya, maka petugas seyogyanya harus mempunyai suatu pedoman, antara lain peraturan-peraturan tertulis yang mencakup ruang lingkup tugas-tugasnya tersebut." Dilihat dari pandangan ini maka dapat dikatakan bahwa aparat pemerintah sebagai petugas penegak hukum dalam rangka melaksanakan peraturan perundangundangan tentang perlindungan terhadap pekerja kontrak sangat menduduki tempat yang strategis. Seperti yang dikatakan oleh Sorjono Soekamto (1986:56) bahwa faktor petugas memainkan peran penting dalam berfungsinya hukum. Kalau peraturannya sudah baik, akan tetapi kualitas petugas kurang baik, maka akan terjadi masalah. Demikian pula, apabila peraturannya buruk, sedangkan kualitas petugasnya baik, kemungkinan pula akan timbul masalahmasalah.

Sehubungan dengan kepastian hukum dan penegakkan hukum, maka apabila kita menelaah lebih jauh hasil , maka dapat dikatakan bahwa kepastian hukum dan penegakkan hukum bagi para pekerja kontrak di daerah penelitian tidak ada, karena banyak sekali pelanggaranpelanggaran yang didapat di lapangan tidak dapat diselesaikan secara hukum dan tidak memberikan perlindungan kepada pekerja selaku manusia yang mempunyai harkat dan martabat. Padahal tujuan negara adalah untuk memelihara ketertiban umum untuk itu negara membutuhkan hukum dan sebaliknya juga hukum dijalankan dan ditegakan melalui otoritas negara.

\section{Kebijakan Pemerintah Dalam Rangka Perlindungan Hukum Bagi Pekerja kontrak yang di PHK}

Keberhasilan

pelaksanaan perlindungan hukum kepada pekerja kontrak atau outsourcing di Kota Ambon tergantung kepada faktor kebijakan dan penghambat pemerintah dalam pelaksanaan tugasnya. Mengingat bahwa suatu peraturan perundang-undangan mempunyai sasaran berlaku dan efektifitas berlakunya ditentukan pula oleh pelaksanaanya, maka kalangan aparat pemerintah sebagai 
pelaksana dari peraturan undang-undang itu dituntut untuk terlebih dahulu mengetahui secara baik tujuan dan kegunaan peraturan perundang-undangan tersebut, sehingga sekaligus dapat mengimformasikan atau mensosialisasikan kepada masyarakat. Selama ini masalah pekerja kontrak yang ada di Kota Ambon telah diupayakan penanggulangannya oleh pemerintah daerah setempat dengan jalan memberikan sosialisasi yang diupayakan untuk diadakan perlindungan kepada pekerja kontrak ini. Dari hasil penelitian tergambar ada beberapa kebijakan dan hambatan terkait dengan perlindungan hukum bagi pekerja kontrak.

Kebijakan yang diambil terkait dengan perlindungan hukum bagi pekerja kontrak yang ada di di Kota Ambon seperti terlihat pada hasil penelitian di beberapa instansi. Konfederasi serikat buruh sejahterah Indonesia (KSBSI) kordinator wilayah Propinsi Maluku Yaheskel Haurissa mengatakan bahwa Sebenarnya setiap perusahaan harus memberikan upah minimum proponsi (UMP) sesuai dengan SK Gubernur, dan ada kedapatan bahwa di Kota maupun kabupaten belum ada anggaran untuk mengawasi dan kurangnya tenaga pengawas untuk mengawasi setiap proyek pemerintah tapi sangat berdosa jika dikatakan bahwa tidak ada anggaran untuk mengawasi pekerja yang ada di Kota ambon. Beliau juga mengatakan bahwa terjadinya pelanggaran upah di Maluku khusus kota Ambon karena kurangnya pemahaman pimpinan perusahaan atau buruh tentang hak dan kewajiban mereka yang diatur dalam ketentuan UU terkait dengan penyelenggaraan upah karena kurangnya sosialisasi baik oleh pemerintah, pengusaha dan serikat buruh dan masih kurang pengawasan yang dilakukan oleh pemerintah kepada pekerja kontrak terutama dari Dinas Nakertrans.

Wawancara juga dilakukan dengan Sekretaris Dinas Nakertrans Kota Ambon, hasil wawancara diperoleh penjelasan bahwa mereka sering melakukan sosialisasi terkait dengan hak-hak pekerja tetapi pelaksanaannya tidak dilakukan secara rutin tergantung kepada ada atau tidaknya anggaran untuk sosialisasi, menurut beliau materi sosialisasinya kerap menyangkut hakhak pekerja dan serta kewajiban melapor dari pemilik usaha tentang jumlah tenaga kerja yang dipekerjakan.

$$
\text { Sosialisasi yang dilakukan }
$$
pemerintah tidak rutin setiap waktu mengakibatkan tidak adanya pemahaman hukum bagi mereka-mereka terutama terkait dengan pekerja

Berdasarkan data yang didapatkan di lapangan maka terlihat ada faktor-faktor yang menghambat penegakan hak asasi manusia pekerja kontrak ini, terutama berasal dari pemilik usaha yang sebenarnya sudah ada aturan yang diatur dalam undangundang tenagakerjaan dan UU HAM tentang perlindungan kepada para pekerja kontrak terutama mengenai hak-hak mereka apabila terjadi pemutusan hubungan kerja, namun kadang pemilik itu pura-pura tidak tahu tentang hak-hak mereka. Yang kedua dari pekerja kontrak itu sendiri dimana di dapati ada pekerja kontrak yang dipekerjakan di PT. Telkom yang bekerja tanpa adanya penandatanganan kontrak terlebih dahulu hanya karena terpaksa untuk mendapatkan uang untuk menyambung hidup dan keluarga langsung menerima tawaran yang diberikan tanpa melalui suatu penandatangan kontrak kerja.

Hambatan yang ketiga datangnya dari pemerintah khususnya pemerintah Kota Ambon adalah perpanjangan tangan dari pemerintah pusat, jadi setiap produk UU atau instrument HAM yang telah dibuat oleh pemerintah pusat itu implementasinya harus dilakukan oleh pemerintah kota karena sekaligus melaksanakan kewajiban dan tanggungjawab pemerintah untuk memenuhi dan meningkatkan hak asasi manusia di daerah.

Bagi manusia yang beradab,siapa saja, dimana saja pasti mengakui bahwa hak asasi manusia (HAM) merupakan hak yang secara kodrati melekat pada diri manusia baik sebagai individu, anggota keluarga, 
ataupun anggota masyarakat internasional dan hak asasi manusia yang bermakna kebebasan dasar tidak dapat diingkari, karena pengingkaran terhadap hak asasi manusia berarti pengingkaran terhadap harkat dan martabat kemanusiaan.

Hak asasi manusia dianggap sebagai etika politik modern dengan gagasan inti adanya tuntutan moral yang menyangkut bagaimana manusia wajib memperlakukan manusia, sehingga secara potensial amat kuat untuk dilindungi orang dan kelompok yang lemah terhadap kewenangan mereka yang kuat karena kedudukan, usia, status dan lainnya.

Menurut Saparinah Sadli, defenisi hak asasi manusia yang dianut dalam piagam hak asasi manusia secara kodrati universal dan abadi sebagai anugrah Tuhan Yang Maha Esa, meliputi hak untuk hidup, hak berkeluarga, hak mengembangkan diri hak keamanan dan hak kesejatraan, yang oleh karena itu tidak boleh diabaikan atau dirampas oleh siapapun (Saprinah Sadli, 2000:82).

Hak asasi manusia yang dituangkan dalam ketentuan Undang-Undang Dasar 1945 terdapat dalam pasal 28. Dalam Pasal 28 A Undang-Undang Dasar 1945 menyebutkan bahwa "Setiap orang berhak untuk hidup serta berhak mempertahankan hidup dan kehidupannya". Pasal 28 D Undang-Undang Dasar 1945 menyebutkan bahwa (1). Setiap orang berhak atas pengakuan, jaminan, perlindungan dan kepastian hukum yang adil serta perlakuan yang sama dihadapan hukum. Ayat (2) menyebutkan bahwa Setiap orang berhak untuk bekerja serta mendapat imbalan dan perlakuan yang adil dan layak dalam hubungan kerja. Pasal $28 \mathrm{G}$ Undang-Undang Dasar 1945 menyebutkan bahwa (1) Setiap orang berhak atas perlindungan diri pribadi, keluarga, kehormatan, martabat dan harta benda yang dibawah kekuasaannya, serta berhak atas rasa aman dan perlindungan dari ancaman ketakutan untuk berbuat atau tidak berbuat sesuatu yang merupakan hak asasi. (2). Setiap orang berhak untuk bebas dari penyiksaan atau perlakuan yang merendahkan derajat martabat manusia dan berhak memperoleh suaka politik dari negara lain.

Pasal $28 \mathrm{H}$ ayat (3) Undang-Undang Dasar 1945 menyebutkan bahwa Setiap orang berhak atas jaminan sosial yang memungkinkan pengembangan dirinya secara utuh sebagai manusia yang bermartabat.

Pasal 28 I ayat (2) Undang-Undang Dasar 1945 menyebutkan bahwa Setiap orang berhak bebas dari perlakuan yang bersifat diskriminatif atas dasar apapun dan berhak mendapatkan perlindungan terhadap perlakuan yang bersifat diskriminatif itu. Sedangkan dalam ayat (4) disebutkan bahwa Perlindungan, pemajuan, penegakan dan pemenuhan hak asasi manusia adalah tanggung jawab negara, terutama pemerintah. Pasal $28 \mathrm{~J}$ ayat (1) UndangUndang Dasar 1945 menyebutkan bahwa Setiap orang wajib menghormati hak asasi manusia orang lain dalam tertib kehidupan bermasyarakat, dan bernegara. Sedangkan ayat (2) menyebutkan bahwa Dalam menjalankan hak dan kebebasannya, setiap orang wajib tunduk kepada pembatasan yang di tetapkan dengan UndangUndangdengan maksud semata-mata untuk menjamin pengakuan serta penghormatan atas hak dan kebebasan orang lain dan untuk memenuhi tuntutan yang adil sesuai dengan pertimbangan moral, nilai-nilai agama, keamanan dan ketertiban umum dalam suatu masyarakat demokratis.

Pasal 1 ayat (1) dari Undang-Undang Nomor 39 Tahun 1999 tentang Hak Asasi Manusia mendefenisikan hak asasi manusia sebagai seperangkat hak yang melekat pada hakekat keberadaan manusia sebagai mahluk Tuhan Yang Maha Esa, dan merupakan anugrahNYA yang wajib dihormati, dijunjung tinggi dan dilindungi oleh Negara, hukum, pemerintah dan setiap orang demi kehormatan serta perlindungan harkat dan martabat manusia yang selanjutnya ada juga dalam pasal 38 Undang-Undang Nomor 39 Tahun 1999 tentang Hak Asasi Manusia 
yang mengatakan bahwa: (1) Setiap warga negara, sesuai dengan bakat, kecakapan, kemampuan, berhak atas pekerjaan yang layak, (2) Setiap orang berrhak dengan bebas memilih pekerjaan yang disukainya dan berhak pula atas syarat-syarat ketenagakerjaan yang adil, (3) Setiap orang, baik pria maupun wanita yang melakukan pekerjaan yang sama, sebanding, setara, dan serupa, berhak atas upah serta syarat-syarat perjanjian kerja yang sama, (4) Setiap orang, baik pria maupun wanita, dalam melakukan pekerjaan yang sepadan dengan martabat kemanusiaannya berhak atas upah yang adil sesuai dengan prestasinya dan dapat menjamin kelangsungan kehidupan keluarganya.

Negara wajib melindungi dia sebagai seorang pekerja kontrak dalam melakukan pekerjaannya. Dan negara juga harus melindungi dia dari perbuatan-perbuatan yang merendahkan harkat dan martabatnya selaku pekerja kontrak.

Hak adalah kepentingan yang dilindungi, sedangkan kepentingan adalah tuntutan perorangan atau kelompok yang diharapkan untuk dipenuhi. Kepentingan pada hakekatnya, mengandung kekuasaan yang dijamin dan dilindungi oleh hukum dalam melaksanakannya. Apa yang dinamakan hak itu sah, karena dilindungi oleh sistim hukum (Sudikno Mertokusuma, 1996:41).

Seperti yang telah diuraikan dalam bab-bab terdahulu mengenai perlindungan hukum yang dikemukakan oleh Philipus M. Hadjon (1987:2) bahwa: perlindungan hukum bagi rakyat dibedakan atas dua macam yaitu: (1) perlindungan hukum preventif dan (2) perlindungan hukum represif. Pada perlindungan hukum preventif, kepada rakyat diberikan kesempatan untuk mengajukan keberatan (inspraak) atau pendapatnya sebelum sesuatu keputusan pemerintah mendapat bentuk yang defenitif. Dengan demikian perlindungan hukum yang preventif bertujuan untuk mencegah terjadi sangketa, sebaliknya perlindungan hukum yang represif bertujuan untuk menyelesaikan sangketa. Perlindungan hukum yang preventif sangat besar artinya bagi tindakan pemerintah yang didasarkan pada kebebasan bertindak, karena dengan adanya perlindungan hukum yang preventif pemerintah terdorong untuk bersikap hatihati dalam mengambil keputusan yang didasarkan kepada diskresi. Dengan pengertian yang demikian, penangan perlindungan hukum bagi rakyat oleh pemerintah dan masyarakat termasuk katagori perlindungan hukum preventif dan represif.

Sarana perlindungan hukum yang represif bagi pekerja kontrak dimaksudkan adalah pemberian perlindungan hukum dalam hal mendapatkan pekerjaan yang layak, sesuai dengan harkat dan martabatnya sebagai manusia.

Bertolak dari apa yang dikemukakan di atas, maka sebenarnya jelas bahwa perlindungan terhadap pekerja kontrak adalah upaya pemenuhan hak-hak asasi manusia, dimana salah satu aspek penting penerapan dari suatu kaidah hukum adalah penegakkan hukum (law inforcement). Suatu perangkat hukum baru dikatakan efektif apabila hukum tersebut dapat diimplementasikan sanksinya dan dapat ditegakkan apabila hukum tersebut ada yang melanggarnya.

Pengakuan dan perlindungan hak asasi manusia yang dijadikan sebagai unsur utama negara hukum merupakan jabaran dari konstitusi, bahwa negara ini berdasarkan atas hukum dan tidak berdasarkan atas kekuasaan maka perlindungan merupakan jaminan kalau harkat dan martabat manusia memperoleh tempat yang layak di depan hukum dan pemerintah, dan dalam posisi ini manusia manusia merupakan subjek yang mendapat jaminan perlindungan hak-hak kemanusiannya.

Hak asasi manusia adalah hak dasar atas hak pokok yang dibawa manusia sejak lahir sebagai anugrah Tuhan Yang Maha Esa dan hak asasi ini menjadi dasar hak dan 
kewajiban yang lain (Darji Darmodiharjo dan Sidharta, 2002).

Negara dalam hal ini mempunyai kewajiban melindungi seluruh masyarakatnya dengan aturan-aturan atau undang-undang yang mewadahi tingkah laku mereka dalam hal mendapatkan, pelayanan kesehatan, pekerjaan dan lain-lain.

\section{P E N U T U P}

\section{Kesimpulan}

Berdasarkan apa yang telah diuraikan, maka dapat ditarik kesimpulan bahwa Pekerja kontrak atau outsourcing sebagai mahluk Tuhan Yang Maha Esa memiliki hak asasi sejak dilahirkan, sehingga tidak ada manusia atau pihak lain boleh merampas hak tersebut dan hak asasi pekerja kontrak ini diakui secara universal sesuai yang tercantum dalam Piagam bangsa-Bangsa tahun 1984 tentang Hak Asasi Manusia (HAM). Secara moral semua Negara dituntut untuk menghormati, menegakan dan melindungi hak pekerja kontrak. Salah satu bentuk hak asasi pekerja kontrak adalah jaminan untuk melindungi sesuai dengan nilai-nilai agama dan kemanusiaan serta pancasila dan tujuan Negara yang tercantum dalam UUD 1945. Tetapi sampai detik ini hak-hak asasi pekerja khusus pekerja kontrak yang sudah ada dalam peraturan perUndang-Undangdi Negara kita belum bisa diterapkan terhadap kasus-kasus yang terjadi pada pekerja kontrak khususnya di Maluku.

\section{Saran}

Berdasarkan apa yang disimpulkan diatas, maka akan dikemukakan beberapa saran sebagai berikut:

1. Sebaiknya dibuat perlindungan hukum kepada pekerja khusus pekerja kontrak untuk menangani pelanggaran hak asasi manusia pekerja

2. Perlu diadakan penegakan hak asasi manusia terhadap pekerja khusus pekerja kontrak dengan kesengguhan menerapkan penegakan sanksi terhadap para pengusaha.

\section{DAFTAR PUSTAKA}

Ali, Achmad, 2002. Menguak Tabir Hukum (Suatu Kajian Filosofis dan Sosiologis), PT Toko Agung Tbk. Jakarta.

Aswanto,1999, Jaminan perlindungan Ham dalam KUHAP dan peranan bantuan Hukum Dalam Penegakan HAM di Indonesia.

C.,de Rover, tanpa tahun, To Serve And To Protect, Acuan universal penegakan HAM, Terjemahan oleh Supardan Mansur, 2002. PT Raja Grafindo Persada, Jakarta.

Dadang Juliantara, 1999. Jalan Kemanusiaan, Panduan Untuk Memperkuat Hak Asasi Manusia, Lapera Pustaka Utama Yogyakarta.

Darmawan Arif Danang, 2008. Mengikat Tali Komunitas Memutus Rantai Kekerasan Terhadap Perempuan, Media Wacana, Yogyakarta.

Daud Ali, Muhammad, 2004, Hukum Islam, Jakarta, PT. Radja Grafindo Persada.

Hadjon P.M. 1987, Perlindungan Hukum bagi rakyat di Indonesia, Bina Ilmu Surabaya.

Mahfud MD,Moh. 1998, Politik Hukum di Indonesia, Pustaka LP3ES Indonesia, Jakarta.

Peter Baehr,et.al,2001, Instrumen Internasional Pokok-Pokok Haka Asasi Manusia, terjemahan Oleh Yayasan Obor, Jakarta

Philippe Nonet dan Philippe Selznick, 1978, Hukum Responsif, Pilihan di Masa Transisi, terjemahan Oleh 
Rafael Edy Bosco, 2003, Huma, Jakarta

Scott Davidson, 1994, Hak Asasi Manusia

Terjemahan oleh A.Hadyana

Pudjoatmaka, 1994, PT Pustaka utama Grafiti, Jakarta

Saraswati LG. DKK, 2006, Hak Asasi Manusia Teori, Hukum, Kasus.

Satjipto Rahardjo, 1983. Masaalah Penegakan Hukum, Suatu Tinjauan Sosiologi Hukum, Sinar Baru Bandung.

Hukum di Indonesia, Kompas
Jakarta

Sudikno Mertokusuma, 1996, Mengenal Hukum Suatu Pengantar, Liberty Yogyakarta

\section{Lain-lain}

Undang-Undang Dasar 1945 (sesudah amandemen)

Undang-Undang No 13 Tahun 2003 Tentang Ketenagakerjaan

Undang-UndangNo. 39 Tahun 1999 tentang Hak Asasi Manusia.

Kepmenakertrans 220/MEN/X/2004 tentang syarat-syarat penyerahan sebagian pelaksanaan pekerjaan kepada perusahaan

Kepmenakertrans No. 100/2004 tentang ketentuan pelaksanaan perjanjian kerja waktu tertentu. 